\title{
Different Approaches on the Investigation of Ground
}

\section{Water}

Cássio Stein Moura ${ }^{1}$, Roberto Heemann ${ }^{1}$, Moisés Razeira ${ }^{2}$, Daniela Govoni Sotelo ${ }^{1}$, Gabriela Borges Soares ${ }^{1}$, Giovanna Ramos Garcez ${ }^{1}$, Júlio César Gall Pires ${ }^{1}$, Vanessa da Conceição Osório ${ }^{1}$ and Heldiane Souza dos Santos ${ }^{1}$ 1. Institute of Petroleum and Natural Resources, Pontifical University of Rio Grande do Sul, Porto Alegre 90619-900, Brazil

2. Federal University of the Pampa, Caçapava do Sul 96570-000, Av. Ipiranga, 6681, Prédio 96 J, Porto Alegre, RS, Brazil

\begin{abstract}
In this paper we discuss ways to obtain information about the quality of ground water and their availability. We classify the different approaches in two categories: geophysical methods, e.g., electroresistivity sounding, seismic survey, gravimetry, MT (magnetotelluric) method, and geochemical methods. The former ones are able to provide information on the geological structure, meaning depth, range, amount of water and possible connections among different exploration areas or regions at risk due to contamination. On the other hand, the last ones provide information about the quality of water and the possible of use for agriculture, industry or human consumption. As a case study we aim at the Guarani Aquifer, more specifically at its recharge zone on the southern rim.
\end{abstract}

Key words: Drought, ground water, geophysics, geochemistry.

\section{Introduction}

Drought used to be a problem of some specific regions in Brazil but over the past few years it has become a problem on regions where water was historically abundant. The possible reasons range from the occurrence of the La Ninã and El Niño-Southern Oscillation climate pattern to human actions on the atmosphere. Brazilian economy is strongly dependent on the rain regime for some important economic pillars are agriculture and cattle raising. The industrial sector linked to the primary sector is very dependent on water resources for food processing. Due to the strong fluctuation on the rain regime and the spreading of drought over the country, one possible solution to overcome the lack of meteoric water is the exploration of ground water.

It is well known that in the southern region of Brazil is located an enormous groundwater reservoir called Guarani Aquifer that has been partially studied

Corresponding author: Cássio Stein Moura, Dr., prof., research fields: underground water, inversion methods, molecular dynamics, nanostructures, experimental physics. and there is still a huge lack of knowledge about it. Its groundwater could be used for the drought mitigation problem. The United Nations [1] computed that for producing $1 \mathrm{~kg}$ of grain requires approximately 1,500 liters of water while $1 \mathrm{~kg}$ of beef requires 15,000 liters. Brazilian government is concerned about economic losses and social problems caused by natural disasters. Since 2015, the project Subsurface Mapping of the Guarani Aquifer has been supported by Science, Technology and Telecommunication Ministry.

In 2012, the National Geologic Service published a study [2] based on the distributions of sedimentary basins on the state. The information about the Guarani Aquifer shows in a preliminary way that: there is a large compartmentalization of the system which means percolation through adjacent areas is opposed by the presence of geological barriers; that the reservoir depth varies from region to region; and that the salinity level varies along the geographical distances. The determination of these properties is fundamental to compute the water extraction cost and the possible uses, e.g., human or animal consumption, agriculture or industry. 
Brazil is a country with high per capita water availability. However, according to the National Water Agency [3], the country has uneven distribution of water resources. Examples are: the Amazon Hydrographic Region which has the less populated region of Brazil, with about $80 \%$ of water availability; Northeast which has low water availability and is a highly populated region; South Region which has a high demand for irrigation water; South and Southeast Regions together which have high demand besides having large amount of ionic substances launched in the rivers, compromising the quality of the waters [4].

There are regions where it is not possible to supply the population with surface water because of pollution or overexploitation. Therefore, groundwater will tend to be increasingly studied. Knowledge about groundwater is considered to be much lower than the knowledge about surface water. When it comes to groundwater there is a lag in data such as the quality, quantity and physicochemical characteristics of these waters [5].

The state of Rio Grande do Sul has a significant share one of the largest aquifers in the world. The Guarani Aquifer is the third largest in the world in terms of volume, behind only to the Nubian Sandstone and North Sahara aquifers, both located in Africa [6].

The Guarani Aquifer is a heterogeneous system of sedimentary layers from several origins which have different porosities and permeabilities. These layers were deposited over a period of more than 100 million years and their characteristics influence the aquifer potentiality [7]. It occupies an area of approximately 1.2 million $\mathrm{km}^{2}$, in which about two thirds of this area is disposed in Brazilian territory. The state of Rio Grande do Sul has $157,600 \mathrm{~km}^{2}$ of the aquifer's area [8] The Guarani Aquifer is a hydrostratigraphic unit associated to a set of rocks formed by sediments originating from the mechanical accumulation of dendritic particles (produced by the decomposition of rocks and silicates: gravel, sand, silt and clay) from the Paraná Basin (Brazil and Paraguay), the
Chacoparanaense Basin (Argentina) and the North Basin (Uruguay) [7, 9].

The waters range from very recent to more than 35,000 years. The outcrop area in the State of Rio Grande do Sul is located in the State Central Depression, ranging from the cities of Santo Antônio da Patrulha to Santana do Livramento. The confined area is present in the northern part of the state and is confined by the volcanic rocks of the Serra Geral Formation from the western border to the coastal region of the state [10].

One cannot ignore the human effects on the quality of the water stored in the subsurface. Several kinds of industries discard their toxic waste on the land surface which can lixiviate down to the water table. Urban waste if not well conditioned may contaminate ground water. Industrial scale agriculture uses large amounts of chemical fertilizers and agrotoxics that can easily reach the water table. In recent years the oil and gas industry has made use or rock fracturing in order to exploit shale gas. During this process some chemicals are introduced into the ground and may endanger the water quality. Therefore, besides knowing the quantity and localization of ground water it is important to prevent its pollution caused by anthropic influences.

Several geophysical and geochemical techniques can be used to investigate and characterize a ground water reservoir. In this paper we present and discuss some of them having as case study the Guarani Aquifer.

\section{Electroresistivity Sounding}

For a full monitoring of the wells located in the Guarani Aquifer region, the GIGA (Interdisciplinary Group for Applied Geophysics), founded in 2008 at PUCRS, suggests the electrical resistivity method to determine the depth and the quality of underground water reservoirs. Special attention was given to the recharge zones, where cities, farms and industrial plants are located requiring large amounts of water for their use and, at the same time, presenting a large 
contamination risk to the aquifer. The geoelectrical methods were originated in the 18th century, when rock resistivity and soil conductivity were discovered. In the early 20th century, works with mineral prospection were carried out as the first application. Researchers such as Conrad Schlumberger and Frank Wenner had a great value in the development of the electrical resistivity method [11]. Electrical methods are currently applied in 55\% of groundwater geophysical studies, according to geophysical journals in the last 22 years, which included works carried out around the world [12].

The ER (electrical resistivity) sounding is a geophysical method to determine the electrical resistivity of soils and rocks, and then to identify them lithologically. This avoids excavations which require lots of time and huge costs. Among the main applications are geological mapping, mining, civil engineering, environment and groundwater prospecting.

The resistivity of geological materials can vary within an extensive range. Igneous rocks, for example, present high resistivity values, sedimentary rocks are more conductive and metamorphic rocks present intermediate resistivity values.

The definition of electrical resistivity is given by Ohm's laws. Physically, electrical resistance represents the difficulty of establishing an electric current in a given conductor. In geology, the classification of the types of conductivity is given from the mechanisms of propagation of electric current. The electronic conductivity occurs due to the transport of electrons in the rock matrix. The ionic conductivity is related to the displacement of ions existing in fluid that fill the pores, sediments or fissures of the rocks, and this is the type of mechanism of greater relevance in the studies applied to hydrogeology [11]. The electrical resistivity method is based on the study of the electric potential in the natural electric fields, as well as on the electric potential of the artificially induced fields.
The usual configuration is formed by a set of four electrodes, called A, B, M and N. The pair of electrodes $\mathrm{AB}$ is used to inject the electric current in the subsoil whilst the pair MN is used to measure the electrical potential difference generated as a result of the current flow. Several arrays can be employed, depending on the complexity and purpose of the survey. These procedures are related with the position of the electrodes on field and offer great versatility to the method. The main arrays applied are: dipole-dipole, Wenner and Schlumberger.

In the last years the electrical resistivity method has been applied around the world in the groundwater exploration, geoelectric and hydrogeological characterization of water resources and in the study of underground water contamination.

In the Guarani Aquifer located in São Paulo, the hydrological characterization of the recharge area has been performed. Information about the flow, depth and different lithologies was obtained [13]. At Bacia do Alto Rio Curaçá, BA, a hydrogeological model of water storage and transmission was proposed in order to explain salinization mechanisms [14]. In Minas Gerais, a study of the water flow in the recharge area of an aquifer was performed. The electrical resistivity method was efficient for assessing the recharge process, even when dealing with subtle differences in water content [15].

In Tamilnadu, Southern India, pollution was identified in highly industrialized areas, due to contamination of the soil and shallow water table by effluents [16]. In Rio Claro, SP, monitoring of the contamination plume was performed, in 1999 and 2008. Two flow directions were found and the plume showed to become bigger and deeper during this time span [17].

In a region close to Rio Claro, SP, a study about natural vulnerability of aquifers was carried out, relating hydraulic accessibility and attenuation capacity [18]. In Canoas, RS, a study performed by Petrobras identified more and less protected zones, defined by the presence of a clayey layer above the 
confined aquifer [11]. In Texas, USA, the impacts on the quality of aquifers due to $\mathrm{CO}_{2}$ leakage were studied [19].

\section{Seismic Survey}

A practical way to investigate different stratigraphic layers which may reveal geological structures with potential water storage is to drill wells in the region of interest. However, this technique, besides being economically unfavorable, can facilitate the entry of contaminants once the confining layers are broken.

To minimize the likelihood of contamination it is common to use some seismic refraction geophysical technique which allows indirect quantification of acoustic properties from seismic waves [20]. This study addresses the behavior of the seismic primary wave with which it is possible to determine the propagation velocity of the wave in the geological environment and, after that estimate, the composition and the depth of different layers [21]. This information can contribute to ascertaining the vulnerability of underground water reserves. It is important to have information on the wells depth in order to calibrate the mechanical wave velocity through the different rock layers [22].

The seismic waves are mechanic vibrations, which are propagated in the geologic layers and may be natural or artificial. The propagation of the seismic waves follows the Snell-Descartes' law. According to this law, when a seismic wave finds an interface which separates two layers with different acoustic impedances, reflected and refracted waves are generated. The acoustic impedance is defined as the product of the rock density by the wave propagation velocity in the layer. A wave passing from a medium with a lower velocity to one with a higher velocity will be reflected back in the same angle as the incident wave and a refracted wave will be transmitted following Snell's law. When the incident wave reaches the surface at a critical angle, refraction occurs at $90^{\circ}$ and the seismic wave propagation occurs along the separation interface between the two layers. Since density increases with depth, propagation velocities are greater at deeper layers, as it is found in most geological situations. Therefore, full refraction is favored in the geological environment.

We have used seismic sounding to investigate shallow water resources in the Guarani Aquifer recharge region. The seismic pulse is produced through mechanical percussion, where, for small arrangements (up to $60 \mathrm{~m}$ ) it is sufficient to use an 8 $\mathrm{kg}$ hammer. The method used has the purpose of mapping refractors in subsurface and it becomes fundamental to choose the geometry and the dimensions of the arrangements. This procedure ensures that the same segment of the spread (set of geophones and connecting cable) detects the arrivals of refracted wave fronts. The seismograph used is a multi-channel Seistronix device with a maximum spread of $120 \mathrm{~m}$ and 12 geophones.

After data collection, comes the step of seismogram analysis that is a graphical representation of the distance of the receivers by the signal travel time of the mechanical wave back to the surface [23].

In such a graph, straight lines are drawn representing the travel time of the wave. We use the reciprocal $\mathrm{ABC}$ method whose processing depends on 5 shooting points, where three of them are located inside the spread and two outside the seismic line with a distance of at least half the length of the spread.

They are known as direct shot and reverse shot. Fig. 1 shows a representation of the method applied in our experiments. The arrangement of the shooting points allows sweeping the refractor entirely, making possible the use of the Phantom Arrival method [24] which is based on the delay time of the wave, providing a more accurate strategy specifically with respect to the depths of the layers. With such method we are able to identify geological structures near the surface that play important roles on the aquifer structure. 


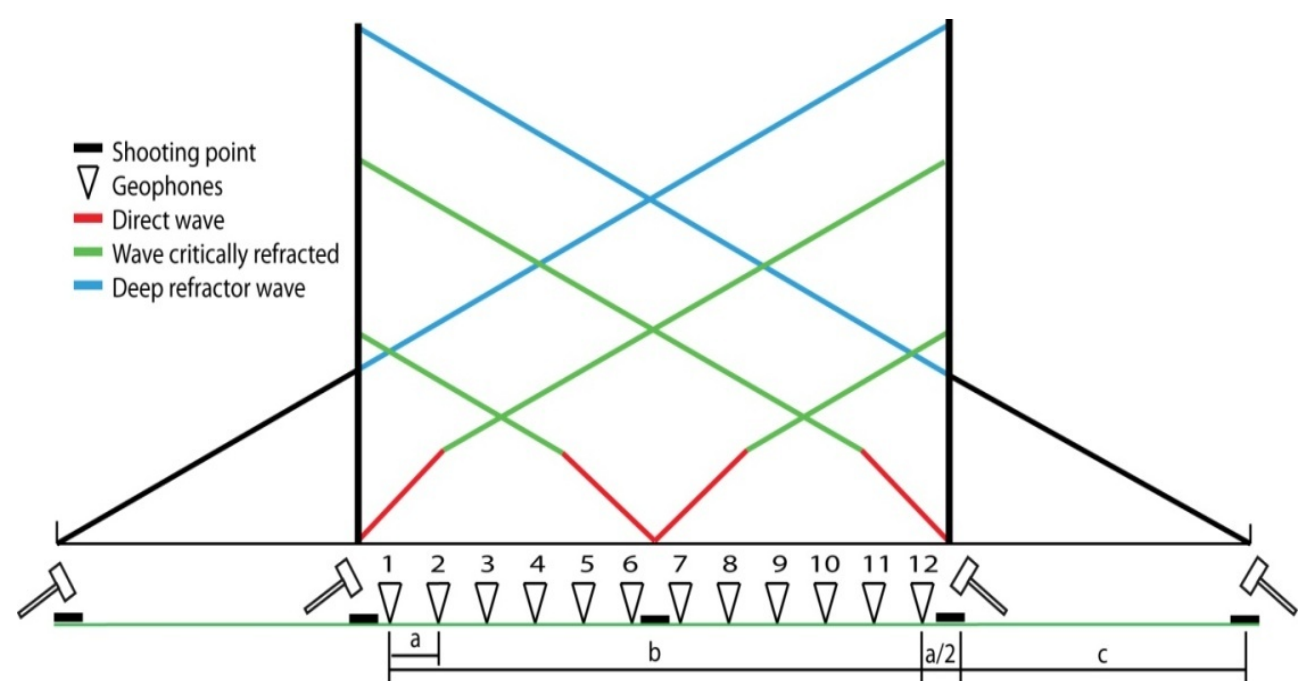

Fig. 1 Representation of shooting points and travel time graphs for the ABC seismic method. In (a) spacing between geophones, (b) length of the arrangement and (c) spacing of the distant shots.

\section{Gravimetry}

Gravimetric surveys are based on measurements of the variation of the Earth's gravity field. In other words, gravimetry consists of a set of techniques whose purpose is to measure the intensity of gravity on a determined region. The fundamental law of the gravimetric method is Newton's Law given by the equation

$$
F=G \frac{m_{1} m_{2}}{r^{2}}
$$

where, $F$ is the force of attraction between the masses $m_{1}$ and $m_{2}, r$ is the distance between the masses, considering them being of negligible size, and $G$ is the universal gravitation constant whose value in SI units is $6.67 \times 10^{-11} \mathrm{~m}^{3} /\left(\mathrm{kg} \cdot \mathrm{s}^{2}\right)$. The data obtained in gravimetric measurements are the acceleration of gravity usually expressed in $\mathrm{m} / \mathrm{s}^{2}$, or, more commonly, mGal which equals $0.001 \mathrm{~cm} / \mathrm{s}^{2}$.

Field missions carrying a gravimetrer are able to perform local measurements at predetermined points. Such missions require using dedicated human resources, personnel dispatching and logistic expenses. An option to such procedures is the use of open available satellite data. The GRACE (Gravity Recovery and Climate Experiment) consists of two identical artificial satellites that were placed in the same polar orbit at approximately $500 \mathrm{~km}$ of altitude and separated by $220 \mathrm{~km}$ from each other. They use a $\mathrm{K}$-band resonant microwave system that gauges the speeds and distances between the two satellites due to Earth's gravitational field changes that are correlated to changes in mass (topography) and irregularities in mass density distributions. These satellite path variations allow the determination of tiny gravitational alterations. The two satellites are capable of sensing a change in their separation equivalent to one micron [25]. The GRACE products are obtained, processed and archived by the SDS (Science Data System) and distributed by JPL (Jet Propulsion Laboratory), UTCSR (University of Texas Center Space Research) and GFZ (GeoForschungsZentrum Potsdam). SDS releases the gravity field models of the Earth and distributes them via the PODAAC (Physical Oceanography Distributed Active Archive Center) and/or ISDC (Information System end Data Center) after the validation of the mathematical models.

Thus, using GRACE data, one can estimate the variation of the water mass in an underground reservoir such as the Guarani Aquifer. During the seasonal recharging period the amount of water within the geologic formation increases and tends to be depleted in the dry period due to its exploration. This variation causes changes of gravity due to alterations 
of masses in a thin layer of the Earth's surface. Moreover, a plastic deformation of the crust takes place and can be observed through calculation of the Stokes coefficients provided by GRACE mission [26]. Therefore, it is possible to foresee the future of the aquifer based on the balance between recharging and exploration.

\section{MT (Magnetotelluric) Method}

The MT method uses the natural temporal variation of the terrestrial EM (electromagnetic) field as a signal source to estimate the electrical conductivities in subsurface in the frequency domain. It is assumed that the incidence of the EM field on Earth is a flat EM wave that moves vertically to Earth. The diffusion of the magnetic field within the Earth induces electric currents called telluric currents. They generate new secondary magnetic fields that are measured by the MT sensor. The intensity of the current is small for it is a natural source, thus a small source of noise may cause interference in the measurement. These interferences can be derived from human action or natural sources of EM fields, such as antennas, electric fences, lightning, solar explosions, among others [27]. The laws of physics, which control these EM induction processes are represented by the Maxwell's equations. The method output is an impedance tensor which is interpreted in terms of resistivity as a function of position and depth by means of mathematical models. These models need some initial hints to start from and can be 1D (one-dimensional), 2D (two-dimensional) or 3D (three-dimensional) [27, 28].

This method has been widely used in several countries around the world due to the unique capacity of exploration at shallow and great depths without the use of an artificial source. Possible uses encompass prospection of water, oil and gas. The method is well suited to the case of the Guarani Aquifer for in several regions the water reservoir is located underneath a deep basalt structure reaching more than $1 \mathrm{~km}$ of depth. An advantage of the method is the ability to provide data with little or no environmental impact [28]. Another advantage of this method is the characterization of regions with local electrical heterogeneities, usually associated with fault structures, and the recognition of areas with large sedimentary thicknesses. In addition, there is the low cost of fieldwork compared to other geophysical methods, such as seismic sounding. Therefore, the MT method turns to be an adequate way to map the Guarani Aquifer.

\section{Integration of Geophysical Data}

It is well known that, in many cases, the ground prospection with geophysical techniques is a kind of problem known as inverse problem [29].

When the equations that describe the system, the boundary and initial conditions are known, the problem is said mathematically well posed and thus solvable. Otherwise, the problem is said ill-posed and is of an inverse type.

The inverse problem has no single solution. That is, it is ambiguous. Thus the geophysical prospection presents ambiguities in the determination of geological structures in the ground.

A technique that minimizes these ambiguities requires the use of multiple geophysical methods, like the ones described in the present article. Once the data are collected they are integrated (processed simultaneously) to produce an approximation to the solution in order to determine the properties and geological structures of the system being studied, e.g., the Guarani Aquifer.

One of the most promising tools for analyzing multiple geophysical data with minimal human interpretation is machine learning tools. The most widely used machine learning tools nowadays are neural networks and genetic algorithms.

Thus, the method of data processing by machine learning appears to be the most suitable for the study of the Guarani Aquifer. The use of these techniques 
nowadays represents a new research area in geophysics and is in the state of the art of the field.

\section{Geochemistry}

The recharge area and a part of the confined area of the Guarani Aquifer is located at its southern rim and presents an adequate region to be investigated due to its shallow depth and accessibility through water wells already in use by the population. In the eastern part of this recharge area is located the city of Santa Cruz do Sul in the Central Depression region of the State of Rio Grande do Sul [30]. The city presents the following lithological units: sandstone, shales, siltstones and argillites [10]. Its geographic

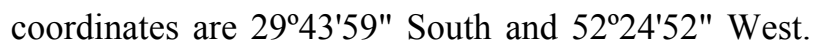
It has an average altitude of $122 \mathrm{~m}$ and a total area of $794.49 \mathrm{~km}^{2}$, with $156.96 \mathrm{~km}^{2}$ of urban area and 637.53 $\mathrm{km}^{2}$ of rural area. Geologically, the outcropping units in the study areas correspond to the Neotriassic and Jurassic-Euclidean supersequences of the Paraná Basin, formed respectively by the Rosário do Sul Group, represented by the member Alemoa of the Santa Maria Formation and by the Caturrita Formation, and the São Bento Group, composed of the Botucatu and Serra Geral formations [31]. The main economic activities in the city are tobacco, food, clothing, metallurgy, plastic and rubber industries. The survey of land use in Santa Cruz do Sul indicates that the city's most intense agricultural crops are tobacco, irrigated rice, corn and soy. These activities were investigated by several authors due to the high potential risk of contamination of the soil and groundwater by the substances used in their control, which allow diffuse contamination, making it difficult to identify and control them [32].

Pesticides have been widely distributed on the region and their traits have been detected in all areas of the environment: air, water and soil [33]. According to data extracted from the final Report of the Health Surveillance Center of the Health Department of Rio Grande do Sul, the most likely pesticides to be found in this area are: 2,4-D, glyphosate, imazetapyr, fipronil, clomazine, imazetapique and quincloraque [34].

Knowledge of groundwater quality used by the community is extremely important. Mainly in the rural areas of the city, where it is common practice to drill artesian wells and cacimbas to supply houses, which, in the majority of cases, are done without any analysis of water quality prior to the start of use neither constant monitoring. There are families that have reported on the use of the artesian well by the family for more than five decades without ever having performed an analysis of the quality of the well. In many cases, the land where the artesian well that supplies the family is housed is the same as for housing chicken or pigs and growing tobacco, corn, soybeans or rice. For these cases, it would be important to monitor water quality, since both animal waste and pesticides applied to plantations have great potential to reach groundwater. The main concern regarding the contamination by agrochemicals in groundwater is due to the fact that the environment provides some resistance to these substances due to the lack of the necessary conditions for their degradation, such as the existence of low temperatures, a reduced amount of oxygen, absence of light and little microbial activity [32].

The main processes that occur after the application of pesticides in the soil are leaching, surface runoff, sorption, chemical and biological degradation and volatization. Leaching is characterized by infiltration of the products to the deeper layers. It depends on soil moisture and porosity, and can reach the water table, being the main mechanism of contamination of groundwater. In surface waters, runoff is characterized as the main threat, which can contaminate reservoirs, lakes and rivers $[35,36]$.

The following physical and chemical parameters are investigated in situ directly from the water collected from artesian wells: temperature, dissolved oxygen, electrical conductivity, $\mathrm{pH}$ and salinity. The 
quantification of metals present in the groundwater occurs through the technique called inductively coupled ICP-OES (inductively coupled plasma optical emission spectrometry). The anions present in these waters are quantified through IC (ion chromatography) and the pesticides present are analyzed by HPLC (high performance liquid chromatography).

The ICP-OES is an analytical technique that quantifies elements (metals, semimetals and rare earths) in several types of samples. It is based on the detection of EM radiation emitted by neutral atoms or excited ions in the regions of the visible and ultraviolet EM spectrum. The fundamental principle of atomic emission spectrometry is the property of atoms emitting EM radiation when subjected to certain conditions. In this case, the ionization of the elements to be analyzed will be done by the inductive plasma of argon. The plasma presents temperature varying between $7,000 \mathrm{~K}$ and $10,000 \mathrm{~K}$ and has sufficient energy to promote the excitation of most of the existing chemical elements, allowing the quantification of a wide range of analytes [37].

Chromatography is the name used to designate a set of techniques where two phases are used, one stationary and the other one mobile, through which the various components of the solution are distributed. The way in which the stationary phase is defined is the type of chromatography. When fixed in a tube through which the mobile phase is required to pass, it is referred to as column chromatography and may be classified as liquid, gaseous or fluid, according to the mobile phase used. Ionic chromatography allows the ionic composition to be separated from a sample by passing it through a column filled with resins or zeolites [38]. Once separated, the ions are identified, detected and quantified. The method can be applied efficiently in potable or groundwater for the determination of bromide, chloride, fluoride, nitrate, nitrite, phosphate, sulphate, calcium, potassium, sodium and magnesium.

HPLC is the most used of all analytical separation techniques due to its sensitivity, its easiness of adaptation to accurate quantitative determinations, its suitability to separation of non-volatile or thermally fragile species and, above all, its wide applicability [39]. HPLC has been used for the determination of pesticides coupled to several detectors, among them the DAD $[40,41]$ and MS [42-44], which help in the identification and quantification of the compounds [45].

Studies of the application of screening models for the assessment of the potential for contamination of groundwater have been increasingly used because of the easiness in obtaining the parameters and the low cost. However, the most commonly used parameters are those adopted by the EPA (Environmental Protection Agency), the GUS (Groundwater Ubiquity Score) index and the GOSS method [46, 47]. All the mentioned methods represent different combinations of parameters such as: water solubility, soil organic matter adsorption coefficient, Henry's Law constant, speciation, half-life in water, half-life in the soil, annual rainfall.

Another widely used assessment methodology, the GOD system, evaluates the vulnerability of the aquifer to contamination. This index is obtained from the product among three evaluated parameters. "G" evaluates the degree of hydrological confinement; "O" stands for the occurrence of the overlying substrate and is related to the lithological characteristics and degree of consolidation of the saturated zone or confining layers (free, confined and semi-confined) and "D" represents the depth of groundwater [48]. Some limitations should be considered in the models presented, such as the absence of data on some substances and mainly their metabolites, as well as the individual evaluation of the compounds to the detriment of the effects caused by their combination, since in many cases several substances are simultaneously applied in the soil $[49,50]$. The models are simplifications of the behavior of pesticides in the environment and therefore a follow-up through the collection and analysis of 
samples is necessary in the validation of the model employed plus the evaluation of how much it diverges from reality.

\section{Conclusion}

The increase of the water demands by mankind has posed a great problem to current society. It is necessary to have a clear view that the surface water per se is not sufficient for the population use: the exploration of underground water is an urgent necessity and presents itself as a great challenge to be overcome. Besides the rational use of underground water there is the need to protect it from pollution. In this paper we discussed some of the geophysical and geochemical techniques that can be used to better understand an underground water reservoir choosing as a case study the Guarani Aquifer.

\section{Acknowledgments}

We acknowledge the Brazilian Coordination of the Improvement of the Graduate Level Personnel (CAPES) for its financial support.

\section{References}

[1] UNWater.org [homepage on the internet]. New York: The United Nations Inter-Agency Mechanism on all Freshwater Related Issues, Including Sanitation; c2014 [updated 2014 Oct 16]. Available from: http://www. unwater.org/statistics/statistics-detail/en/c/211645/.

[2] CPRM. 2012. "Recursos Hídricos Subterrâneos-Levantamento de Recursos Hídricos Subterrâneos." Relatório Diagnóstico 16.

[3] ANA-Agência Nacional de Águas. 2013. Conjuntura dos Recursos Hídricos no Brasil.

[4] Portugal, J. P. S., Reydon, B. P., and Portugal, N. S. 2015. "As águas minerais no Brasil: uma análise do mercado e da institucionalidade para uma gestão integrada e sustentável." Rev. Ambiente e Água 10 (2): 413-30.

[5] Faria, A. M. J. B. 2014. Aquifero Guarani: defesa da soberania e sustentabilidade. Multideia: Curitiba-PR.

[6] UNESCO/IHP. 2003. "Interdisciplinary Approaches in Small Catchment Hydrology: Monitoring and Research." In Proceedings of the 9th Conference of the European Network of Experimental and Representative Basins (ERB) Demänovská dolina (Slovakia), 25-28 September.

[7] Machado, J. L. F. 2005. "Compartimentação espacial e arcabouço hidroestratigráfico do Sistema Aquífero Guarani no Rio Grande do Sul." PhD Thesis, Universidade do Vale do Rio dos Sinos. São Leopoldo.

[8] Silva, P. C. A. 2011. Reserva Hídrica: Aquífero Guarani e seu uso sustentável. Monografia. Pós-graduação do centro de formação, treinamento e aperfeiçoamento da câmara dos deputados. Biblioteca Digital da Câmara dos Deputados. Centro de Documentação e Informação. Coordenação de biblioteca. Brasília.

[9] Rebouças, A. C., and Amore, L 2002. "O Sistema Aqüífero Guarani-SAG.” Revista Águas Subterrâneas 16: $135-43$.

[10] Viero, A. C., and da Silva, D. R. A. 2010. Geodiversidade do Estado do Rio Grande do Sul: Programa Geologia do Brasil. Levantamento da Geodiversidade. Porto Alegre, Brasil: CPRM—Serviço Geológico do Brasil.

[11] Braga, A. C. O., Malagutti Filho, W., and Dourado, J. C. 2006. Resistivity (DC) Method Applied to Aquifer Protection Studies. Revista Brasileira de Geofisica 24 (4): 573-81.

[12] Consórcio Guarani: Tahal Consulting Engineers Ltd., Seinco, S. R. L., Hidroestructuras, S. A., Hidrocontrol, S. A., Hidroambiente, S. A. Técnicas Geofísicas Terrestres Aplicáveis ao Estudo no Sistema Aquífero Guarani (SAG) e Guia Básico de Dados Regionais.

[13] Oliva, A., Gastmans, D., Zamprogno, C. F., Paula e Silva, F., Romualdo, D. B., Lobo, G. A., Lima, W. P., Rocha, H. R., and Chang, H. K. 2006. "Utilização do método da eletrorresistividade na caracterização hidrogeológica de área de recarga do Sistema Aquífero Guarani." XIV Congresso Brasileiro de Águas Subterrâneas.

[14] Lima, A. O. 2010. "Estruturas geoelétrica e hidroquímica do Sistema Aquífero cristalino da Bacia do Alto Curaçá, semi-árido da Bahia." Rev Bras Geof 28 (3): 445-61.

[15] Morais, F., and Bacelar, L. A. P. 2010. "Geofísica Aplicada ao Estudo de Fluxos da Água no Solo." Sociedade \& Natureza 22 (1): 213-22.

[16] Srinivasamoorthy, K., Sarma, V. S., Vasantavigar, M. P., Vijayaraghavan, Chidambaram, S., and Rajivganthi, R. 2009. "Electrical Imaging Techniques for Groundwater Pollution Studies: A Case Study from Tamil Nadu State, South India." Earth Sci. Res. J. 13 (1): 30-9.

[17] Bortolin, J. R. M., and Malagutti Filho, W. 2010. "Método da eletrorresistividade aplicado no monitoramento temporal da pluma de contaminação em área de disposição de resíduos sólidos urbanos." Eng Sanit Ambient 15 (4): 367-74.

[18] Braga, A. C. O. 2008. "Estimativa da Vulnerabilidade Natural de Aquíferos: uma contribuição a partir da resistividade e condutância longitudinal." Rev. Bras. Geof. 26 (1): 61-8. 
[19] Carroll, S. A. 2014. "Key Factors for Determining Groundwater Impacts due to Leakage from Geologic Carbon Sequestration Reservoirs." Int. J Greenhouse Gas Control 29: 153-68.

[20] Nonrandom, O. 2013. "Seismic Refraction Method: A Technique for Determining the Thickness of Stratified Substratum." American Journal of Applied Sciences 10 (8): 857-62.

[21] Michel, G. P., and Kobiyama, M. 2015. "Estimativa da profundidade do solo: Parte 1-Métodos de campo." Revista Brasileira de Geografia Física. 8 (4): 1206-24.

[22] Gandolfo, O. C. B. 2014. A determinação da profundidade do nível d'água pelo método da refração sísmica. Sociedade Brasileira de Geofísica. VI Simpósio Brasileiro de Geofísica. 2014 Out [cited 2014 Nov]; [about p. 5]. Available from: https://www.researchgate.net/publication/268745295.

[23] Schuster, G. T., and QuintusBosz, A. 1993. "Wave Path Eikonal Travel Time Inversion: Theory." Geophysics 58 (9): 1314-23.

[24] Hagedoorn, J. G. 1958. "The Plus-Minus Method of Interpreting Seismic Refraction Sections." Geophysical Prospecting 7 (2): 158-82.

[25] NASA [homepage on the internet]. Houston: Studying the Earth's Gravity from Space: The Gravity Recovery and Climate Experiment (GRACE); c2003. Available from:

http//www.csr.utexas.edu/grace/publications/fact_sheet/in dex.html.

[26] Bonfim, E. P., and Molina, E. C. 2009. "Análise da variação dos elementos do campo de gravidade na Região do Aquífero Guarani a partir dos dados GRACE." Revista Brasileira de Geofisica 27 (1): 17-34.

[27] Guaragna, I. M. 2014. Atenuação de ruidos regionais para dados Magnetotelúricos (MT). Monografia (Universidade Federal Fluminense).

[28] Costa, F. A. 2005. "Investigações Eletromagnéticas na Porção Continental da Bacia do Espírito Santo e suas Adjacências Cristalinas." M.Sc. thessis, Ministério da Ciência e Tecnologia, Observatório Nacional, Departamento de Geofísica.

[29] Telford, W. M., Geldart, L. P., and Sherif, R. F. 2004. Applied Geophysics, 2nd edition. Cambridge: Cambridge University Press. UNESCO/WWAP. Water for People Water for Life. 2003 [updated 2015 Sept. 04]. Available from: http://unesdoc.unesco.org/images/0012/001297/129726e. pdf.

[30] IBGE. Produção Agrícola Municipal-2011. Elaboração: SEPLAG RS/DEPLAN—01/2013.

[31] Noronha, F. D. L., Mizusaki, A. M., and Bressani, L. A. 2012. "O mapeamento geológico-geomorfológico como uma ferramenta para obtenção de informações geotécnicas preliminares: estudo de caso na área urbana de Santa Cruz do Sul (RS, Brasil).” Pesquisas em Geociências 39 (2): 127-45.

[32] Silva, D. R. O., de Avila, L. A., Da Cas Bundt, D. A. A., and Caldas, E. G. P. S. S. 2011. "Ocorrência de agrotóxicos em águas subterrâneas de áreas adjacentes a lavouras de arroz irrigado." Quimica Nova 34 (5): 748-52.

[33] Yadav, I. C., Devi, N. L., Syed, J. H., and Jones, K. C. 2015. "Current Status of Persistent Organic Pesticides Residues in Air, Water, and Soil, and Their Possible Effect on Neighboring Countries: A Comprehensive Review of India." Science of the Total Environment 511: 123-37.

[34] CEVS/SES (Centro de Vigilância em Saúde da Secretaria da Saúde). 2010. Secretaria Estadual da Saúde Governo do Estado do Rio Grande do Sul. Levantamento do Uso e da Criticidade dos Agrotóxicos Usados no Estado do Rio Grande do Sul. Talha-Mar Soluções Ambientais, RELATÓRIO FINAL.

[35] Demoliner, A. 2008. "Otimização e Validação de Metodologia Analítica Empregando SPE e LC-ESI-MS/MS para Determinação de Multiclasses de Agrotóxicos e Metabólitos em Água de Superfície e de Abastecimento Público.” Dissertation, Universidade Federal de Rio Grande, Rio Grande.

[36] Rebelo, R. M., and Caldas, E. D. 2014. "Avaliação de Risco Ambiental de Ambientes Aquáticos Afetados pelo uso de Agrotóxicos." Química Nova 37 (7): 1199-208.

[37] USP (Universidade de São Paulo) Central Analítica, Instituto de Química. Espectrometria de emissão óptica com plasma-ICP OES [homepage on the Internet]. São Paulo. [Updated 2017 Apr 27]. Available from: http://ca.iq.usp.br/novo/paginas_view.php?idPagina=13.

[38] Gonçalves, M. L. S. S. 2001. Métodos Instrumentais para análise de soluções. Análise Quantitativa, Lisboa: Fundação Calouste GulBenkian.

[39] Skoog, D. A., Skoog, D. A., Holler, F. G., Nieman, T. A., and Caracelli, I. 2002. Principios de Análise Instrumental (5th ed.). Porto Alegre: Bookman.

[40] Cerejeira, M., Viana, P., Batista, S., Pereira, T., Silva, E., Valerio, M. J., Silva, A., Ferreira, M., and Silva-Fernandes, A. M. 2003. "Pesticides in Portuguese Surface and Ground Waters." Water Research 37: 1055-63.

[41] D’Archivio, A. A., Fanelli, M., Mazzeo, P., and Ruggieri, F. 2007. "Comparison of Different Sorbents for Multiresidue Solidphase Extraction of 16 Pesticides from Groundwater Coupled with High Performance Liquid Chromatography." Talanta 71: 25-30.

[42] Marín, J. M., et al. 2006. "Quantification and Confirmation of Anionic, Cationic and Neutral Pesticides 
and Transformation Products in Water by on-line Solid Phase Extraction-Liquid Chromatography-Tandem Mass Spectrometry." Journal of Chromatography A 1133: 204-14.

[43] Ferrer, I., and Thurman, E. M. 2007. "Multi-residue Method for the Analysis of 101 Pesticides and Their Degradates in Food and Water Samples by Liquid Chromatography/Time-of-Flight Mass Spectrometry." Journal of Chromatography A 1175: 24-37.

[44] Shomar, B. H., et al. 2006. "Occurrence of Pesticides in Groundwater and Topsoil of the Gaza Strip." Water, Air and Soil Pollution 171: 237-51.

[45] Braga, J. W. B. 2007. "Determination of Pesticides and Metabolites in Wine by High Performance Liquid Chromatography and Second-Order Calibration Methods." Journal of Chromatography A 1148: 200-10.

[46] Primel, E. G., ZanellaII, R., KurzII, M. H. S., GonçalvesII, F. F., MachadoIII, S. O., and Marchezan, E, 2005. "Poluição das águas por herbicidas utilizados no cultivo do arroz irrigado na região central do Estado do Rio Grande do Sul, Brasil: Predição teórica e monitoramento.” Quimica Nova 28 (4): 605-9.

[47] Zini, L. B. 2016. "Contaminação de agrotóxicos na água para consumo humano no RS: avaliação de riscos, desenvolvimento e validação de método empregando SPE e LC-MS/MS.” M.Sc. dissertation, Universidade Federal do Rio Grande do Sul, Porto Alegre.

[48] Foster, S., and Hirata, R. 1988. Groundwater Pollution Risk Assessment: A Methodology Using Available Data. Peru Lima: Pan American Centre for Sanitary Engineering and Environmental Sciences (CEPIS).

[49] Lourencatti, C., Spadotto, C. A., Santiago-Silva, M., and Ribeiro, M. L. 2005. "Avaliação do potencial de contaminação de águas subterrâneas por pesticidas: comparação entre métodos de previsão de lixiviação." Pesticidas: Risco Exotoxicológico e Meio Ambiente 15: $1-14$.

[50] Neto MLF. 2010. "Norma Brasileira de Potabilidade de Água: Análise dos parâmetros de agrotóxicos numa abordagem de avaliação de risco." PhD Thesis, Escola Nacional de Saúde Pública Sergio Arouca. Rio de Janeiro. 